\title{
A review on induced mutagenesis in soybean
}

\author{
Mudasir Hafiz Khan* and Sunil Dutt Tyagi \\ Division of Plant Breeding and Genetics, Kisan (P.G) College, Simbhaoli, Ghaziabad (U.P), India.
}

Accepted 18 April, 2013

\begin{abstract}
The history of mutations with early results in soybean has been well documented in the literature available. Mutation breeding has been used in recent years as a valuable supplement to other methods of plant breeding in generating new variability and development of crop varieties with new architecture, superior biochemical constitution and suitable growth and developmental rhythms. The utility of this method is evident from the fact that in several crops induced mutants have been released as new varieties. In this paper, efforts have been made to review the literature on induced mutations in soybean. The different mutagenic agents used for inducing mutations, effects of different mutagenic agents on yield, quality contributing characters and resistance to different diseases have been described.
\end{abstract}

Key words: Glycine max (L.) Merrill, induced mutagenesis, crop varieties.

\section{INTRODUCTION}

Soybean [Glycine max (L.) Merrill] has become the miracle crop of the $21^{1 \text { st }}$ century. It is a triple beneficiary crop, which contains about $40 \%$ proteins, possessing high level of essential amino acids except methionine and cystine, $20 \%$ oil rich in poly unsaturated fatty acids specially omega- 6 and omega- 3 fatty acids, 6 to $7 \%$ total minerals, 5 to $6 \%$ crude fibre and 17 to $19 \%$ carbohydrates (Chauhan et al., 1988). Besides, it has good amount of iron, vitamin B-complex and isoflavones such as daidzein, genistein of glycitin. The presence of calcium and iron makes it highly suitable for women who suffer from osteoporosis and anemia. The isoflavones of soybean have been found to possess health benefits, as they exhibited properties like cancer preventing, combating menopausal problem and helping to recover from diabetics (Chauhan et al., 2002). In the present paper, efforts have been made to review up-to-date literature on induced mutations in soybean.

\section{EFFECT OF MUTAGENIC AGENTS}

\section{Meiosis}

Ahmad et al. (1977) reported paracentric inversions in the hybrids between the two species of soybean as the dose was increased. Qing et al. (1997) reported that after irradiation of soybean seeds for 3 days with $500 \mathrm{rad}$ gamma rays, the number of mitochondria per cell decreased, while the number of vacuoles increased and cell structure changed dramatically with some organelles having disintegrated. Treatment with 5000 rad gamma rays caused significant cell damage and inhibited cell growth. Ping et al. (1998) studied cytomorphology of a male sterile mutant NJ89-1 in soybean and reported that the observations on anther and pollen development showed that NJ89-1 differed from msl-ms6 mutant in many aspects such as abortion stage, meiosis, tetrad formation, pollen wall and anther wall, etc. NJ89-1 displayed similar meiotic abnormalities of asynapsis or desynapsis to those of st2-st5 mutants by differed from st2-st5 mutants in female fertility with females of st2-st5 mutants being strongly impaired.

Bione et al. (2002) observed many univalent a few bivalents in diakinesis of a mutant line BR97-13774H. Telophase II exhibited a varied number of different sized nuclei; pollen sterility was estimated at $93.12 \%$. Bione et al. (2002b) reported that many univalent, few or total absence of bivalents were found in diakinesis of 
BR97-12986H, soybean mutant. Bivalents presented in or two terminal chiasmata, while univalents retained the sister chromated cohesion. Bivalents and most univalents congregated at the equatorial plats, although univalents frequently migrated to the poles prematurely. Laggards resulting from delay in chiasmata terminalization were also recorded. Pollen sterility was estimated at $91.2 \%$ segregation ratio for sterility in this line and its progenies reached 3:1.

\section{Seed germination}

Hassan et al. (1985) irradiated seeds of Bragg, Hodgson and Lee-74 containing 1113\% moisture content with 100 to 500 Gy gamma rays and 5 to 30 Gy fast neutrons and reported that growth inhibition increased with increasing doses and germination was inhibited only at the higher doses. Lee-74 was the most sensitive variety to gamma radiation and Bragg the most sensitive to fast neutron doses above $20 \mathrm{~Gy}$, as revealed by differences in epicotyl length. Bhatnagar et al. (1989) treated seeds of soybean cv. Bragg with EMS (ethyl methanesulfonate) and gamma rays, with or without additional exposure to UV light for2 $\mathrm{h}$ at $260 \mathrm{rim}$ and reported that mutation frequency in the M2 ranged from 2.24 to $22.85 \%$. Among the mutants obtained T-214 was from the $25 \mathrm{kR}$ gamma radiation + UV treatment. It exceeded the parent in germinability by $15 \%$ and was 5 days earlier in maturity.

\section{Seedling survival}

$M_{2}$ seedling survival decreased (in comparison with untreated control) following radiation and chemical treatment. Zakri and Jalani (1986) treated two cultivars (Palmetto and Acadian) of soybean with ethyl methanesulfonate and gamma rays and reported that the cultivar Palmetto showed higher survival percentages following either treatment. $\mathrm{Li}$ (1988) reported that when dry seeds of several soybean varieties were treated with electrons at various doses, marked effects were observed in the M1, on seedling height and survival percentage. Wang et al. (1989) treated seeds of the soybean line LF81-837 with $0.001,0.002$ and $0.005 \mathrm{M}$ $\mathrm{NaNO}_{3}$ at $\mathrm{pH} 3$ and reported that plant survival was reduced by $49.9 \%$ in the $\mathrm{M} 2$, generation when seeds were treated with $0.005 \mathrm{M}$ sodium azide solution. Li et al. (1994) irradiated dried seeds of soybean cv. Changnong 5 with gamma rays ( 120 to $200 \mathrm{~Gy}, 2.28 \mathrm{~Gy} / \mathrm{min}$ ) or an electron beam (180 to $450 \mathrm{~Gy}$ ) and reported that dressing treated seeds with benzamide resulted in a lower survival rate and fertility, but a higher chromosomal aberration rate compared with those treated with gamma rays or the electron beam alone.
Satpute and Fultambkar (2012) treated the dormant seeds of soybean cultivars MAUS-71 and JS-335 with varied concentration of chemical mutagen (EMS) and physical mutagen (Gamma rays). They reported a dose dependant decrease in most of the characters in M1 generation. They further reported that the reduction in germination percent over control was noticed in all mutagenic treatments in both the cultivars, while increased pollen sterility was associated with corresponding increases in dose/ concentration of mutagens

\section{Chlorophyll mutations}

Constantin et al. (1974) reported that fast neutrons and ethyl methane sulphonate (EMS) were the most effective inducers of chlorophyll deficiencies and morphological mutants. Fujii and Tano (1987) reported that the somatic $M$, mutations induced by EMS (ethyl methanesulfonate) and segregation of chlorophyll deficient mutants in the $M_{2}$ were studied in the strain T219. The results indicated that in the $M_{2}$ generation, chlorophyll mutation frequencies were estimated as 0.14 , 0.61 and $0.41 \%$ per $\mu \mathrm{g}$ EMS at treatments with $0.5,0.1$ and $0.2 \%$ EMS, respectively. Harb (1990) treated the two cultivars of soybean with gamma rays and reported that there was large reduction in the chlorophyll and carotenoid contents of mutants.

\section{Leaf mutants}

Badaya and Mehrotra (1974) reported that treatment of presoaked Clark-63 seed with ethyl methanesulphonate, ethyleneimine, and gamma rays resulted in a mutation spectrum for leaf shape and size, leaflet number, and testa colour. Kiang and Halloran (1975) reported that the frequency of mutations induced by ethyl methanesulphonate in the $M_{1}$, and $M_{2}$ generations for leaflet number were in the range 1 to $5 \%$ over all characters. Fujii et al. (1983).

Reported that when soybean seeds were treated with caffeine solutions, the number of mutant spots per leaf on the resulting plants ranged from 3.7 at $0.01 \%$ to 24.8 at $0.05 \%$ caffeine. However, when the seeds were treated with 12-O-tetradecanoylphorbol-l3-acetate (TPA) plus caffeine the number of leaf spots decreased, significantly so in the case of $0.03 \%$ caffeine. TPA alone at concentrations of 1 to $20 \mu \mathrm{g} / \mathrm{ml}$ did not induce any mutations. Fu (1986) treated soybean varieties (("SF" 7919-61 and "SF" 7910-3) with $15 \mathrm{krad}$ of 10Co gamma rays and reported two special mutation types that is two opposite trifoliate leaves per node ("SF"7919-61) and 4-7 leaflets instead of 3 per leaf ("SF"7910-3)). He further reported that these lines showed a higher growth rate, increase in leaf area, stronger stem and lodging resistance 
than tiefeng No. 18.

Culbertson et al. (1991) reported that seeds of soybean genotype T31 were treated with $2.5 \mathrm{mM}$ nitrosomethyl urea [N-methyl-N-nitrosourea] for $3 \mathrm{~h}$. In the $\mathrm{M}_{4}$ generation, 32 plants exhibited puberulence and smooth seed coats. Li et al. (1995) reported that no changes were found in photosynthesis or chlorophyll content with 0,25 or $50 \%(\mathrm{v} / \mathrm{v})$ methanol during 1,2 or 3 weekly applications. Xue-Bai et al. (2000) while studying the mutagenic effect of 60 Co gamma irradiation on soybean observed that the M2 seedling were with one or three primary leaves and joined or wrinkled cotyledons.

\section{Altered stem structure}

\section{Plant height}

Nicolae and Nicolae (1977) treated the seeds of the soybean line B-89/J I with gamma rays and thermal neutrons and observed that most of the mutant lines in M2-M4 were taller than the control line of B-89/11. Fahmy et al. (1997) reported that the increasing doses of gamma-rays were negatively associated with plant height. Kundi et al. (1997) reported that after irradiation of three varieties of soybean viz PK 416, SL96 and PB Soybean No.1 with three doses of gamma rays viz 10, 20 and $30 \mathrm{kR}$, there was marginal increase in mean values for plant height.

\section{Growth type}

Wang and $\mathrm{Yu}$ (1988) reported that three genotypes were exposed to 8 doses of gamma radiation at 2 developmental stages. Following radiation at the VE-V1 stage, growth of the $M_{1}$, generation was reduced more when the same dose was administered at a lower rate. Reductions in growth rate and number of morphological abnormalities were greater at doses of 50 Gy and above. Khvostova (1967) reported gamma rays induced short stemmed and lodging mutants. Mutations for internodal length in $X Z$ generation were recorded by Humphrey (1951).

\section{Stem thickness}

Mutations for stem size were recorded in $\mathrm{M}_{2}$ generations of X-ray irradiated soybean varieties (Humphery, 1951).

\section{Branching}

More densely branched mutants were recorded by Zacharias (1956) in X-ray irradiated material.

\section{Lodging}

Weber and Fehr (1967) studied maturity period in both irradiated and segregating populations and donot observed any difference for lodging.

\section{Alteration of ripening time}

\section{Maturity}

Szyrmer and Boros (1986) studied the maturation period of soybean lines and reported that the maturation period of the mutant was not significantly shorter than in the control varieties. Bhatnagar et al. (1989) treated seeds of soybean cv. Bragg with ethyl methane-sulfonate (EMS) and reported that the mutants were 5 days earlier in maturity. Tulmann and Peixoto (1990) observed some very early mutants with the same level of productivity as in the parent cultivar (Parana) when seeds were treated with $22 \mathrm{kR}$ gamma rays. Mehta et al. (1994) treated a local cultivar of soybean (Kalitur) with gamma rays and EMS. They reported that two mutants namely 7 and 13 were isolated in $M_{2}$ and the maturity period of these mutants were superior as compared to the control treatment of Kalitur. Khudhair et al. (2002) irradiated the seeds of soybean with $0,100,200$, and $300 \mathrm{kR}$ of gamma rays and selected two mutants which were superior in their yield components and earliness in maturity compared with the variant $\mathrm{H} 226$ and other control cultivars.

\section{Number of pods per plant}

Zakri and Jalani (1986) treated two cultivars (Palmetto and Acadian) of soybean with ethyl methane sulfonate and gamma rays and reported that the mutant P6302 had 86 pods/plant compared with 22 for the control.

\section{Pod setting}

Birnberg et al. (1987) reported that when leaves of soybean cultivars Evans and Lincoln were treated with gibberellic acid $\left(\mathrm{GA}_{3}\right)$ about 3 days before anthesis, the fraction of flowers on the associated node that set pods was reduced by 28 to $76 \%$.

\section{Yield}

Skorupska (1984) treated seeds of 14 soybean varieties with $10 \mathrm{kR}$ of gamma rays administered alone or in conjunction with $\mathrm{NaNO}_{3}$ solution, and reported that morphological abnormalities were frequent in all the treatments in $M_{2}$ while, in $M_{3}$, the traits showed the greatest variation for seed yield/plant. Krausse (1989) developed 6 mutant lines, out of which Dorado was the best mutant line having higher yields (1320 to $1560 \mathrm{~kg} / \mathrm{ha}$ as compared to control line $1205 \mathrm{~kg} / \mathrm{ha}$ ). 
Bhatnagar et al. (1990) reported that seeds of blackseeded soybean $\mathrm{cv}$. Bhat were treated with gamma rays (15 to $25 \mathrm{kR}$ ), with or without additional exposure to UV radiation $(2 \mathrm{~h}$ at $260 \mathrm{~nm})$. The results indicated that among the useful mutants identified, T154 from the $20 \mathrm{kR}$ + UV treatment surpassed the parent and local standards for yield. Bhatnagar et al. (1992) irradiated seeds of the soybean cultivars Punjab-1, Gaurav and NRC-I with 15 and $20 \mathrm{kR}$ gamma-rays and observed that in the $M_{3}$ generation, Gaurav showed higher and more significant variability for seed yield and 100 -seed weight than Punjab I and NRC-1. Pavadai and Dhanavel (2005) reported that 100-seed weight and yield per plant decreased with increasing dose of gamma rays.

\section{Seeds/plant}

Increase in average seeds/plant in $x_{2}$ was reported by Sebok et al. (1963). According to Georgiev and Topcieva (1970), the average number of seeds/plant failed to increase with increase in dose but in the variety Adams, dose 4 and $8 \mathrm{kR}$ increased the seeds/plant over the un-irradiated control. Rajput (1987) reported depressive effect of gamma rays on the mean value for seeds/plant which could have been due to polygenornic mutations. These observations were based on $\mathrm{M}_{2}$ of $10,15,20$ and $25 \mathrm{kR}$ doses $\mathrm{kR}$ gamma treated varieties viz., Loppa, T-I S and Columbus. Prakash et al. (1984) observed changes in seed coat colour from black to yellow, dull brown or brown whey they treated Birsa soybean-1, a spontaneous mutant of sepaya black with gamma rays. Also a yellow seeded M2 plant gave 16 promising M3 plants in the same experiment.

\section{Plant vigour}

Seven plants showing marked increase in vigour in $\mathrm{X}_{2}$ generation over normal plants were observed by Humphrey (1951). Further in subsequent generation, Humphrey (1954) confirmed the same.

\section{Alteration of seed storage substances}

\section{Protein content and oil content}

Dahiya (1973) reported that with radiation treatment (gamma rays) the quality of proteins changed. Some of the M2 progenies showed a greater range of variation in the content of methionine and tryptophan. Hiraiwa et al. (1975) reported that treatment of the varieties Mutsumejiro, Raiden and Miyagishirome with 8 and 16 $\mathrm{kR}$ gamma rays, the mean protein contents of the selected $M_{4}$ populations of first two varieties, treated with 8 and $16 \mathrm{kR}$ gamma rays, and of the last variety, treated with $8 \mathrm{kR}$ gamma rays, were significantly greater than those of the untreated controls. In the $M_{5}$ generation, mean protein contents of selected populations of Mutsumejiro and Raiden were significantly higher than those of the controls. Qiu and Gao (1988) reported higher frequencies of mutants with high protein and oil contents using EMS as compared with fast neutrons and these were more highly heritable in $M_{2}$ and $M_{3}$ lines. Nilegaonkar and Agte (1989) reported that when Kalitur, a black seeded soybean cultivar was exposed to physical and chemical mutagens and subsequently studied for changes in electrophoretic and solubility behaviour of proteins, trypsin inhibitor activity and proximate analysis. Mutation induced changes in protein structure and lowered fat percentage. The mutant cv. MACS 107 had a trypsin inhibitor activity significantly lower, by $15 \%$, than Kalitur.

Wang et al. (1989) treated seeds of the soybean line LF81-837 with 0.2 or $0.4 \%$ solutions of ethyl methane-sulfonate (EMS) at $\mathrm{pH} 7$ and reported that treatment of the seeds with $0.4 \%$ EMS followed by selection in the early generations is recommended for improving protein content. Eskins et al. (1991) grow normal green (Clark LI) and mutant yellow (Clark y9y9) mutants in full-spectrum solar irradiation and reported that response of the mutant to light quality indicated that blue light slightly enhanced expression of the mutation at higher irradiances. Rubisco (ribulose-bisphosphate carboxylase) proteins and rubisco activity (leaf area basis) were directly related to irradiance level but were enhanced in blue light over equal irradiance red light. This enhancement was not shown in the presence of farred light. Qing et al. (1996) reported that gamma rays increased the plant peroxides activity at higher doses. Protein content also increased with increasing doses of irradiation.

\section{Resistance to disease}

Tsai et al. (1974) reported that seed of six varieties of soybean were treated with $1530 \mathrm{kR}$ gamma rays or $1 \%$ ethyl methane-sulphonate solution, and about $5000 \mathrm{M}_{3}$ to $M_{6}$ lines, derived from apparently resistant plants, tested for Phakopsora pachyrhizi resistance under natural conditions, followed by repeated selection, five lines showed appreciable resistance, two of which, $\mathrm{CHI}-$ 41 and $\mathrm{CH} 3-77$, were finally selected for production. Smutkupt et al. (1974) reported that seeds of Sansai and SJ2 were treated with 5 to $30 \mathrm{kR}$ gamma rays and seven lines originating from the $M_{2}$ of both varieties were selected in the $\mathrm{M}_{4}$ on the basis of lodging resistance. Nicolae (1979) reported that Cerag I was selected in Algeria from a collection of induced mutants from Romania. Compared with its parent B107/I0 (T) is more resistant to cold and drought. Oh (1983) reported that from $430 M_{3}$ soybean lines, five were selected as 
highly resistant and 20 as moderately resistant. Kwon and Oh (1983) reported that seeds of the soybean varieties Kwangkyo and Kangrim were irradiated with 15 and $20 \mathrm{kR}$ gamma rays. In the M3, 18 mutants from Kwangkyo were selected which showed moderately resistance against soybean mosaic virus. Wang et al. (1986) reported that a cultivar Heinong 26 derived from Dongnong- 4 following gamma irradiation was tolerant to drought and of low temperatures during the seedling stage.

Tulmann et al. (1988) treated three soybean cultivars with gamma irradiation or treated with ethyl methanesulfonate in order to induce resistance to tobacco ring spot nepovirus (causal agent of bud blight) and Phakopsora pachyrhizi and reported that resistant mutants were selected in the $M_{2}$ and $M_{3}$ generation. Oh et al. (1988) reported that seeds of soybean were gamma-irradiated with 15 and $25 \mathrm{kR}$ and mutants were screened for resistance to soybean mosaic potyvirus. Five lines were subsequently selected which showed highly resistance.

Smutkupt et al. (1988) treated seeds of I1 cultivars with gamma-irradiation at 15 and $30 \mathrm{kR}$ and reported that $M_{3}$ bulk and single populations and $M_{2}$ bulk populations were screened for resistance to Phakopsora pachyrhizi at 2 locations. After further selection, 16 lines were selected as $P$. pachyrhizi tolerant mutants. Nazim et al. (1988) reported that seeds of the cultivars Calland, Columbus and Williams were gamma-irradiated with $20 \mathrm{kR} . \mathrm{M}_{2}$ plants were screened against Drechslera [Cochliobolus] australiensis and Alternaria alternata. Their reactions suggested that the induced resistances were polygenically inherited. In the $\mathrm{M}_{3}, 30$ and 25 mutants were true breeding for resistance to $\mathrm{C}$. australiensis and $A$. alternata, respectively.

\section{Resistance to chemicals}

Hendratno (1988) reported seeds of cv. Orba treated with fast neutrons, gamma-rays, ethyl methanesulfonate and sodium azide and observed one mutant which showed high tolerance of $\mathrm{Al}$ toxicity and exceeding Orba in yield by $17 \%$. Sebastian (1989) reported that seed mutagenesis (using $\mathrm{N}$-nitroso- $\mathrm{N}$-methylurea [N-methyl- $\mathrm{N}$ nitrosourea] and ethyl methanesulfonate) followed by selection for resistance to chlorsulfuron yielded a soybean mutant with a high degree of resistance to both post- and pre-emergence applications of a variety of sulfonylurea (SU) herbicides.

\section{Inheritance of quantitative characters}

\section{Heritability}

Singh et al. (1980) reported that when ten varieties were irradiated with 10 to $20 \mathrm{kR}$ gamma rays, the estimates of heritability (broad sense) ranged from 0 to $51 \%$ for days to flowering, 0 to $58 \%$ for days to maturity, 0 to $80 \%$ for plant height, 0 to $49 \%$ for primary branches, 0 to $81 \%$ for pods per plant, 0 to $92 \%$ for seed per pod and 0 to $80 \%$ for yield per plant. Geetha and Vaidynathan (1998) reported an increase was noticed in heritability and genetic advance for some economic traits like seed yield per plant and 100-seed weight in M2 generations. Kumar and Lal (2001) reported that the phenotypic and genetic coefficient of variation and the estimates of heritability in the broad sense significantly increased in the mutagenic populations. Pavadai et al. (2010) reported that variability, heritability and genetic advance as per cent of mean was recorded high for mutagen treated plants than the untreated plants for all the generation. $50 \mathrm{KR}$ of gamma rays treatment was effective than the other mutagenic treatments compared to control.

\section{Genetic divergence}

Mehetre et al. (1996) studied the gamma induced genetic divergence in $\mathrm{M}_{2}$ generation of soybean and reported that the genetic diversity was independent of varieties and doses of gamma rays. Mehetre et al. (1996) opined that the genetic diversity was independent of varieties and doses of gamma rays. They further observed the sufficient amount of variability due to induced mutations for different polygenic characters over the parent variety in $\mathrm{M}_{2}$ families.

\section{ACKNOWLEDGMENT}

The financial support of this research from the Kisan P.G. College, Simbhaoli, Ghaziabad, U.P, India and Ch. Charan Singh, University, Meerut, U.P, India is appreciated.

\section{REFERENCES}

Ahmad QN, Britten EJ, Byth DE (1977). Inversion bridges and meiotic behaviour in species hybrids of soybean. J. Hered. 68: 360-364.

Badaya SN, Mehrotra HN (1974). Morphological variations induced by physical and chemical mutagens in soybean (Glycine max L.). Symposium on use of radiations and radioisotopes in studies of plant productivity. Agron. Abstr. p. 31

Bhatnagar PS, Prabhakar Tiwari SP, Sandhu JS (1989). Improvement of soybean variety 'Bragg' through mutagenesis. Mutat. Breed Newsletter 33:15-16.

Bhatnagar PS, Tiwari S, Prabhakar P (1990). Application of mutagenesis for the improvement of an indigenous black seeded soybean variety of India. Mutat. Breed. Newsletter 36:8.

Bhatnagar PS, Tiwari SP, Singh C (1992). Differential doseresponse of soybean genotypes to mutagenesis with gamma rays. Biovigyanam 18(2):111-113.

Bione NCP, Pagliarini MS, Almeida LA.-de (2002). An asynaptic mutation in soyabean [Glycine max. (L.) Merrill] associated with total absence of sister chromatid cohesiveness. Cytologia. $67(2): 177-183$

Bione NCP, Pagliarini MS, Almeida LA.de (2002b). A new and 
distinctive malesterile, female-fertile desynaptic mutant in soybean (Glycine max.). Heredita 136(2): 97-103.

Birnberg PR, Cordero RF, Brenner ML (1987). Characterization of vegetative growth of dwarf soybean genotypes including a gibberellin-insensitive genotype with impaired cell division. Am J. Bot. 74(6):868-876.

Chauhan GS, Verma NS, Bains GS (1988). Effect of extrusion processing on the nutritional quality of protein in rice-legume blends. Nahrung 32(1):43.

Chauhan OP, Chauhan GS, Singh G, Kumbhar BK, Mishra, DP (2002). Varietal variability in the contents of nutrients and anti-nutrients in different parts of soybean seeds. J. Rural Agric Res. 2(2):42-50.

Constantin MJ, Klobe WD, Skold LN (1974). Mutation induction in soybean. Mutation Breeding Newsletter, 3: 9-10.

Culbertson RDR, Harper JE, Hymowitz T (1991). Chemical mutagenesis of T31 soybean. Soybean Genetics Committee Report. 18:229-233.

Dahiya BS (1973). Improvement of Mungbean through induced mutations. Indian J. Genet. Plant Breed. 33(3):460-468.

Eskins K, Jiang CZ, Shibles R (1991). Light-quality and irradiance

effects on pigments, light-harvesting proteins and Rubisco activity in a chlorophyll- and lightharvesting-deficient soybean mutant. Physiol. Plantarum. 83:(1):47-53.

Fahmy EM, Rashed MA, Sharabash MTM, Hammad AHA, ElDemerdash HM (1997). Effect of gamma rays on yield and its components for some soybean cultivars (Glycine max. L.). Arab Univ. J. Agric. Sci. 5(1):57-68.

Fu LQ (1986). Study of mutants with opposite trifoliate leaves and multi-leaflet leaves in soybean. Mutat. Breed. Newsletter 27:11.

Fujii T, Shizaki M, Fujiki H, Sugimura T (1983). Effect of TPA on the mutagenicity of caffeine in the soybean mutation test. Mutat. Res. $110(2): 263-269$

Fujii T, Tano S (1987). Mutagenic activities of EMS on somatic and recessive mutations in the soybean test system: Annual Rep. Natl. Inst. Genet. Japan. 36:66-68.

Geetha K, Vaidyanathan P (1998). Studies on induction of mutations in soybean (Glycine max. L. Merill) through physical and chemical mutagens. Agric. Sci. Digest. Karnal. 18(1):27-30

Georgiev Z, Topcieva A (1970). Genetica i Selekcija, 3: 403-409.

Harb RKH (1990). Frequency, spectrum, anatomical and chemical studies on soybean chlorophyll mutations. Bull. Faculty Agric. Univ. Cario. 41(3): 595-608

Hassan S, Mohammad T, Khan S, Brunner H (1985). The effect of gamma and fast neutron irradiations on $M$, seedling growth in soybean. Nucleus Pakistan. 22(1-2):19-22.

Hendratno K 1988. Induced mutations in soybean for earliness and tolerance to high concentrations of aluminium in high acid soil. Improvement of grain legume production using induced mutations. Proceedings of a workshop, Pullman, Washington, USA, 1-5 July, p. 463.

Hiraiwa S, Nkamura S, Tanaka S (1975). Induction of mutants with high protein content in soybean. Mutat. Breed. Newsletter 6: 8.

Humphrey LM (1951). Effects of neutron irradiation on soybeans. Soybean Digest. 12:11-12.

Humphrey LM (1954). Induced mutations in soybean. Soybean Digest. 14:18-19.

Khudhair HA, Jasim AM, Nassralla AY, Suhail AK, Abass HA, Hassan AX, Hussain AJ, Mahmood JN (2002). Induction new suitable soybean genotypes for Iraqi environmental conditions. Dirasat. Agric. Sci. 29(1):65-73.

Khvostova VV (1967). Erwin baur. Ged. Vorl. 4:21-27.

Kiang LC, Halloran GM (1975). Chemical mutagenesis in soybean (Glycine max (L.) Merill) using ethyl methane-sulphonate and hydroxylamine hydrochloride. Mutat. Res. 2(3):373-382.

Krausse GW (1989). Early ripening, productive soybean mutant variety suitable for combine harvesting. Mutat. Breed. Newsletter 34:3-4.

Kumar S, Lal JP (2001). Response of selection for grain yield in mutagenic population in lentil (Lens culinaris Medik). Progress. Agric. 1(1):59-62.

Kundi RS, Gill MS, Singh, TP, Phaul PS (1997). Radiation induced variability for quantitative traits in soybean (Glycine max. (L) Merrill). Crop Improv. 24(2):23-1234
Kwon SH, Oh JH (1983). Induced mutation for soybean mosaic virus disease resistance in soybean. Induc. Mutat. Dis. Resist. crop Plants-II. 5:183-191.

Li GQ (1988). Study of the effect of electron beam on soybean radiation mutation. Acta Agric. Univ. Jilinesis. 10(3):57-62.

Li Y, Gupta G, Joshi, JM, Siyumbano AK (1995). Effect of methanol on soybean photosynthesis and chlorophyll. J. Plant Nutr. 18(9):18751880.

Li-GuoQuan,Yu-ShaoHua Li-Meng, Piao-TieFu, Chen-Guang, YuanYaPing, Bao-HePing, Xu-YaoKui, Li GQ, Yu SH, Li M, Piao TF, Chen G., Yuan YP, Bao HP, Xu YK (1994). Effects of benzamide on radiative mutation in soybean. Acta Agric. Nucleatae.Sinica. 8(3):141-148.

Mehetre SS, Mahajan CR, Hajare DN, Desai NS (1996). Assessment of gamma induced genetic divergence in $\mathrm{M} 3$ generation of soybean Adv. Plant Sci. 9(1):39-42.

Mehetre SS, Mahajan CR, Shinde RB, Ghatge RD (1996). Assessment of Gamma induced genetic divergence in м2 generation of Soybean. Indian J. Genet. 56(2):186-190.

Mehta AK, Mehta SK, Tiwari AS (1994). Improvement of genetic architecture of a local cultivar Kalitur of soybean by mutation. Indian

J. Genet. Plant Breed. 54(4): 357-359:

Nazim M, Hosary AA. Rady MS (1988). Induced mutations for disease resistance to leaf spot fungi in soybean. Improvement of grain legume production using induced mutations. Proceedings of a workshop, Pullman, Washington, USA. 9:383-397.

Nicolae I (1979). A soybean mutant variety in Algeria. Mutat. Breed. Newsletter. 14:5.

Nicolae I, Nicolae F (1977). Inducing favourable mutations by irradiating soybean. Annales de P Institute. National Agronomigua (ELHarrach), 7(3):51-57.

Nilegaonkar S, Agte V (1989). Induced variation in chemical composition of black seeded soybean variety - Kalitur. J. Food Sci. Technol. 26(5):256-258.

Oh JH (1983). Induced mutations for soybean mosaic virus resistance. Mutat. Breed. Newsletter 21:6.

Oh JH, Kwon SH, Song HS, Kim JR (1988). Induced mutations for varietal improvement in soybean. Improvement of grain legume production using induced mutations. Proceedings of a workshop, Pullman, Washington, USA. 7:355-370.

Pavadai $P$, Dhanavel D (2005). Effect of gamma rays on yield and its components in soybean [Glycine max (L.) Merrill. Var. Co-1]. Crop Res. 30(3):459-461.

Pavadai P, Girija M, Dhanavel D (2010). Effect of Gamma Rays on some Yield Parameters and Protein Content of Soybean in M2, M3 and M4 Generation. J. Exper. Sci. 1(6):08-11.

Ping YS, Yi GJ, Qing XH (1998). A genetic cytomorphological study on the male sterile mutant NJ 89-1 in soybean. Soybean.Sci. 17(1):3238.

Prakash R, Trivedi HBP, Kerketta V, Haque-MF, Prakash R (1984). Mutation breeding research in soybean in India. Soybean Genet. Newsletter 11:43-44.

Qing-Yu-Zhang (1997). Studies on and application of the variations in characters in soyabean progeny produced by irradiation with $60 \mathrm{Co}$ gamma rays. J. Henan Agric. Sci. 1:68.

Qing-Y-Z, Zhang FH, Fan-Zhan B, Huang-XL (1996). Studies on the radiation effect of $60 \mathrm{Co}$ gamma -rays on the soyabean plant. $\mathrm{J}$. Henan Agric. Sci. 6:15-17.

Qiu GJ, Gao S (1988). Studies on physically and chemically induced soybean mutations of high protein and oil content and their genetic pattern. Improvement of grain legume production using induced mutations. Proceedings of a workshop, Pullman, Washington, USA, 1-5 July, pp. 421-433.

Rajput MA (1987). Induction of polygenic variance in soybean. Soybean Newsletter, 14: 117-119.

Satpute RA, Fultambkar RV (2012). Effect of mutagenesis on germination, survival and pollen sterility in $\mathrm{M} 1$ generation of soybean [Glycine max (L.) Merill]. Int. J. Recent Trends in Sci. Technol. 2(3):30-32.

Sebastian SA, Fader GM, Ulrich JF, Forney DR, Chaleff RS (1989). Semi-dominant soybean mutation for resistance to sulfonylurea herbicides. Crop Sci, 29(6):1403-1408. 
Singh BB, Upadhyayam HD, Corbin FT (1980). Induced genetic variability for qualitative and quantitative characters in soybean. World Soybean Research Conference II, Abstracts pp. 42-43.

Skorupska H (1984). Identification and evaluation for mutation of agricultural characters in soybean. Soybean Genet. Newsletter 11:5359.

Smutkupt S, Phrek G, Ramanujan S, Iyer. RD (1974). Improvement of soybean protein by mutation breeding in Chiang Mai, Thailand. Proceedings of the Second General Congress of the Society for the Advancement of Breeding Researches in Asia and Oceania. Session $X$. Breeding for protein nutritive quality. 7:662-668.

Smutkupt S, Wongpiyasatid A, Lamseejan S (1988). Improvement of rust resistance in soybean by mutation breeding. Improvement of grain legume production using induced mutations. Proceedings of a workshop, Pullman, Washington, USA, 7:371381

Szyrmer J, Boros L (1986). Performance of early maturing soybean lines obtained from a mutation breeding programme. Improvement of grain legume production using induced mutations. Proceedings of a workshop, Pullman, Washington, USA, 1-5 July, pp. 411419.

Tsai KH, Lu YC, Oka HL, Oka-H (1974). Mutation breeding of soybean for the resistance to rust disease. SABRAOJ.6(2):181-191.

Tulmann, NA, Menten JOM, Ando A, Alberini J, Peixoto, TC (1988). Induced mutations for disease resistance and other agronomic characteristics in bean (Phaseolus vulgaris L.) and soybean (Glycine max (L.) Merrill). Improvement of grain legume production using induced mutations. Proceedings of a workshop, Pullman, Washington, USA, 26:167-187.
Tulmann NA, Peixoto TC. (1990). Early maturing and good yield mutants in soybean (Glycine max. (L.) Merr.) in Brazil. Mutat. Breed. Newsletter 36:9.

Wang BR, Wang LZ, Weng XY, Chen Y, Wu HL, Xu XC, Wang PY (1986). Soybean variety Heinong No. 26. Mutat. Breed. Newsletter 27:10-11.

Wang PY, Yu BS (1988). Preliminary study on gamma-rays chronic radiation for growing plants in soybean. Soybean Genet. Newsletter. 18:82-85.

Wang PY, Wang LZ, Zhang JZ (1989). Induced protein content mutation in soyabean. Soybean Genet. Newsletter 16:38-40.

Weber CR, Fehr WR (1967). Effect of hybridization and thermal neutron irradiation on quantitative characters of soybeans. Crop Sci. 7:78-81.

Xue-Bai, Meng-Li Fen, Zhao-XiaoNan, Guo-YuHong, Liu-BinHong (2000). Mutagenic effect of 60Co gamma irradiation on soybean plants. Soybean Sci. 19(2):150-153.

Zacharias M (1956). Mutationsversuche an Kulturpflanzen VI Rontgenbestrahlungen der Sojabohne (Glycine soja (L. ) Sieb. et Zucc ) Zuchter. 26:321-338.

Zakri AH, Jalani BS (1986). Improvement of soybean through mutation breeding. Improvement of grain legume production using induced mutations Proceedings of a workshop, Pullman, Washington, USA, 1-5 July, pp. 451-461. 